\title{
Issues in Quality of Primary Education in Backward Areas of Jhargram Sub-Division: An Exploration of Policy Options for Adjustment, Revitalization and Expansion
}

\author{
Mrityunjoy Jana ${ }^{1}$, Ansar Khan ${ }^{2}$, Soumendu Chatterjee ${ }^{3}$ \\ ${ }^{I}$ Department of Education, Vinayaka Missions University, Salem, India \\ ${ }^{2}$ Department of Geography and Environment Management, Vidyasagar University, Midnapore, India \\ ${ }^{3}$ Department of Geography, Presidency University, Kolkata, India
}

\begin{abstract}
Since the Universal Declaration of Human Rights was adopted in 1948, efforts have been made by countries (both developed and developing) to universalize primary education. This movement was renewed by the recent Jomtien and Dakar Framework for Action- the Education for All (EFA) conferences and declarations. In this regard study further found that the quality of schooling was declining due to the factor issues in quality of primary education in backward areas of Jhargram sub-division: ineffective leadership, poor training of teachers, low salary of teachers, limited and often ineffective and problematic professional development opportunities for teachers, a focus on quantity rather than quality, a weak economic environment, low participation of parents and commercialization of teacher training colleges. The study showed that the effort to provide quality education for all citizens remains a challenge for the government. On the basis of these findings, it can be stated that the Indian government has a long way to go to achieve the Education for All (EFA) goals within the customary stated timeframe. Poor quality schools compromise the entire system of human capital development as these results in students who are unprepared for secondary and tertiary education, and ill-equipped for lifelong learning. Hence, improving the quality of education for students in primary schools is a prerequisite for developing the human resource base required to meet the changing demands of the twenty-first century. It is also crucial to achieve the EFA goals that stress the delivery of quality primary education for every citizen before 2015.The findings of this study are whispered to have some practical implication, which might highlight areas of intervention to improve the quality of primary education.
\end{abstract}

Keywords: Quality Education; Primary Education; Backward Areas; Jhargram Sub-Division

\section{Introduction}

Education is universally acknowledged in a vast body of literature as an essential element in the process of national development (UNESCO, 2005; GEC, 2000; UNESCO, 1997; TGE, 1993; Lockheed \& Verspoor, 1991; Psacharopoulos, 1985).Today, with a greater understanding of the function that education has in society and in the nation as a whole, the world is striving to deliver primary education to every child. This goal has been on the international agenda since the Universal Declaration of Human Rights affirmed in 1948 that elementary education was to be made freely available and compulsory for all children in all nations. This call was recently renewed by the Jomtien and Dakar framework for action Education for All (EFA) conferences and declarations. Accordingly, all nations, both developed and developing ones, are to prioritize the delivery of universal primary education.

Universal completion of primary education by 2015 was also included among the United Nations Millennium Development Goals (MDGs). All 191 members of the United Nations pledged to meet these goals. The Millennium Development Goals are eight international development targets set forth by the United Nations, adopted by world leaders in 2000 and set to be achieved by 2015. The advocates of Universal Primary Education (UPE) stated that mass education will result in an increased supply of educated human power, accelerated economic growth, greater social justice, reduced regional disparities and improve social welfare (Chimombo, 2005). Correspondingly, several authors(Auger,1987; Haddad,1990; Tahir,2003) justified the need for universal primary education in the following way: it is the birth right of every citizen that promotes equality among members of society, a weapon for the eradication of ignorance, poverty and disease, an instrument for the development of national identity and unity, and prerequisite for participation in politics, government, national development issues and further learning for individual and social development. However, it is strongly believed that achievement of UPE depends on the quality of education (UNESCO, 2004). Improving quality of education is the best way to improve access to education. Similarly, the World Bank (as cited in Mirza, 2003) confirmed that the best way to improve access is to improve quality, which would make going to school or staying a more attractive option from both the parent and children perspective. 
Good quality primary education is increasingly recognized as an important foundation for economic growth and as instrumental in the attainment of other development objectives. As the proverb goes, "Give a man a fish and he will eat for a day; teach him how to fish and he will eat for life". People who have received quality education can not only fulfill their potential, but also contribute to their communities. Quality education is of critical importance and very demanding in the $21^{\text {st }}$ century, where countries are confronted with new economic, social and cultural challenges in which knowledge, skills, values and attitudes will play a central role. With the tremendous growth in school enrolments throughout the world, earlier priority to educational expansion and access is now being replaced by plans and policies calling for a higher quality of schooling. Concern with improving the quality education in schools has started receiving the highest priority in almost all countries throughout the world. This concern has become universal in both developed and developing countries, in those that have achieved total access as well as in those still striving for access (Reddy, 2007). Both the World Declaration on Education for All (1990) and the Dakar Framework for Action (2000) recognize quality as a most important condition for achieving Education for All.

The Dakar Framework states that quality is at the heart of education. Goal 2 commits nations to providing primary education of good quality and no one should be denied this opportunity. Goal 6 includes commitments to improving all aspects of the quality of education and ensuring excellence of all so that recognized and measurable learning outcomes are achieved, especially in literacy, numeracy and essential life skills. Hence, the issue of quality in education has become a global concern. The EFA global monitoring report of 2006, by stressing the importance of quality, noted that a child denied the right to quality primary education is not only deprived, but also disadvantaged for life - unable to cope with situations requiring reading, writing and arithmetic- unless given access to educational opportunities later, in adolescence or adulthood. Primary education is so solid foundation where the skills of the majority of the labour force and the knowledge of intellectuals are built. Therefore, the goal of achieving quality education should be emphasized in the course of universalizing it. However, according to UNESCO (2005), in many countries that are striving to guarantee all children the right to education, the focus on access often overshadows attention to quality.

A number of reports indicated that in the effort to guarantee primary schooling to every number of societies, a focus on access has been complicated by many problems which affect the quality of education the children receive (World Bank, 2007). Likewise, the problem of quality in primary education has become a serious concern of the Paschim Medinipur District Primary School Council, educators and teachers (As per Census 2001 where Rural Female Literacy is below 46.13\% and the Gender gap is above 21.59\% in Paschim Medinipur, at Gopiballavpur-1 and Nayagram block of Jhargram sub-division). Schools teacher plays a crucial role in leading and managing the planning, delivery, evaluation and improvement of the education of all in a community through the strategic deployment of resources.

The role of head teacher leadership in all aspects of school success has been highlighted and confirmed as the link between effective school leadership and effective schools (Fullan, 2005; Sergiovanni, 2001; Barth, 1991). Acknowledging the important role that schools head teacher play in the education system, this study was designed to examine barriers to delivery of primary education in it consists ofJhargram municipality and eight community development blocks: Binpur-I, Binpur-II, Jamboni, Jhargram, Gopiballavpur-I, Gopiballavpur-II, Nayagram and Sankrail in Paschim Medinipur district from in-service Diploma in Elementary Education D.El.Ed (ODL-mode) trainees head teachers and teacher-in-charge of Jhargram Banibhavan Primary Teachers' Training Institute and Pratap Chandra B.Ed College, in order to gain insights into their own experience. To pursue this objective, the study analyzed the major educational problems found in primary schools and that threaten the quality of education. The aim of this qualitative study is to examine the major educational problems that significantly influence the delivery of quality education to citizens. To this end, the study aims to identify problems that threaten the quality of education, and to propose solutions. An attempt is also made to examine the implications of the findings to achieve the EFA goals. The present paper also puts forward some recommendations relevant to the findings of the study.

\section{Superiority of Quality Education: An Outline}

Quality has become a controversial issue internationally and is interpreted differently by individuals, institutions, and organizations. It is an elusive concept that has many definitions as there are categories of stakeholders. This is mainly due to the fact that quality in education is a complex and multifaceted concept embedded in political, cultural and economic contexts (Reddy, 2007; Fredriksson, 2004; Mirza, 2003). In the same vein, Csizmadia (2006) states that quality has no single, absolute, agreed or universally accepted definition; there exists a range of overlapping interpretations. Its definition is open to changing contexts and to a new understanding of educational challenges (UNICEF, 2000). Although it has become a concept which people confidently talk about when marketing or selling their products or services in business, education, and training environments, defining it is not as easy. As Reddy (2007) explains, this has been largely due to board interpretation of the term both within and across countries, reflecting the values and priorities of the different 
stakeholders along with the complexities of the teaching learning process. Adam (cited in Reddy,2007) views quality as a process and suggests that the nature of intra-institutional interaction of students, teachers, administrators, materials and technology in educational activities, as well as how the 'quality of life' of the school is valued, determines quality. Furthermore, he remarks on the difficulty of measuring the educational process.

According to Harvey and Green (1993), quality can be viewed as exceptional, as perfection (or consistency), as fitness for purpose, as value for money and as transformative. The same authors describe these concepts in the following way; quality as exceptional or excellence- as something special, distinctive, something that exceeds very high standards and passes a set of required standards. Quality as perfection or consistency results in flawless outcome. The quality culture of ensuring that things are done right the first time is being promoted by this notion, which proposes that the product or service should be judged by its consistency or, in some cases, its reliability. Quality as fitness for purpose means that quality derives its significance from the purpose of the product or service. Quality is thus judged in terms of the extent to which an institutional product or service meets its purpose. Moreover, Quality as value for money situates quality within the context of return on investment. If the outcome can be achieved at a lower cost, or a better outcome can be achieved at the same cost, the customer has a quality product or service.

This approach views the performance of any programme or institution from the financial perspective. Finally, according to the notion of quality as transformation, quality is judged in terms of change. In the education and training sense, transformation simply refers to the empowerment of learners as a whole. They enter certain programmes with no knowledge or limited knowledge and their participation allows them to learn, which implies transformation or change. All in all, researchers have suggested that the concept of educational quality is complex, elusive, multidimensional and embedded in social contexts, values and cultures. Hence, different definitions of quality have been adopted.

\section{Database and Methods}

Social science research is complex, diverse and pluralistic. However, there is no single best research approach that fits all research problems. Each research approach has its relative strengths and weakness (Dawson, 2002) and no single approach is necessarily ideal (Hamersley, as cited in Lloyd-Jones, 2003). The selection usually depends on the researcher's perception regarding the construction and production of knowledge and the suitability of a research approach for a particular context. As Bryman (1984) describes, the problem under investigation properly dictates the method of investigation. Bearing this in mind and the purpose of the study, we chose the qualitative approach, which is holistic and contextual, and focuses on design and procedures to gain real, rich and deep data for a greater understanding of the entire situation. Moreover, we adopted the qualitative approach because our concern is to define the issue under investigation, seeking insights into the actors' perspectives rather than statistical analysis.

According to Bogdan and Biklen(1992), a person's own biography helps to define a study; that is to say, his or her interests or concerns about certain events or situations would be suitable criteria. In addition, it should be important to the researcher because "Without a touch of passion, you may not have enough to sustain the effort to follow the work to the end". In the same vein, Merriam (1998) asserts that a case can be selected based on personal interest. Guided by the aforementioned assumptions, the Pratap Chandra College of Education and Jhargram Bani Bhaban Primary Teachers' Training Institute for Girls', which are located about $156 \mathrm{Km}$ to the west of capital city, Kolkata, was selected for this study.

The target population for the study consisted of school Head Teacher and Teacher-in-Charge coming from all parts of Jhargram sub-division to attend in-service teachers training programme for development their professional competency at the Pratap Chandra College of Education and Jhargram Bani Bhaban Primary Teachers' Training Institute for Girls'. With regard to the sampling method, participants were located purposefully. As Merriam (1998) states, qualitative researches should locate a group of participants rich in knowledge and experience. Selection proceeded until we ensured that no new perspective or data were obtained from every participant, since the purpose was to maximize information on the issue under consideration. Therefore, participants were located based on the following attributes: Time Commitment- their agreement to participate in the study; Participants' Workplace- to examine the experiences of different regions; Participants' Experience-year of service; and Participants' gender- both male and female participants were involved.

The study involved a total of 52 participants, 13 of whom were female Head Teacher and Teacher-inCharge. The qualitative research method was selected for this study in order to generate data rich in detail and embedded in the context. Accordingly, we collected data using semi-structured interviews and focus group discussions since our main concern was to greater understanding of the phenomenon under study. Each selected participant was interviewed separately, but focus group discussions (consisting of 10-15 individuals) were conducted to see how members debated with each other. Qualitative data analysis is a complex process that involves moving back and forth between concrete data and abstract concepts, between inductive and deductive 
reasoning, and between description and interpretation (Merriem, 1988). Qualitative enquiry involves the simultaneous processing of description, analysis and interpretation. A description seeks to construct data out of people's experiences and their views of reality. Analysis of collected data is ongoing in qualitative research and being with data collection (Glesne, 1999; Merriem, 1988). Taped interviews and Focus Group Discussion (FGDs) were transcribed verbatim and the data organized, categorized, synthesized and thematically analyzed to generate a description of information about events. Finally, researcher interpreted by sorting the responses identifying similar responses and noting unique responses. Then researcher searched for meaning of words and phrases.

Researchers grouped the individual answers into the topical areas that researcher established to identify patterns of responses. The sorting, grouping, and deriving of meaning assisted us in making sense of the data. The phrases frequently voiced by the participants were together as a theme and one of the quotes that describes the theme in a better way used in this research report. This was done instead of repeatedly writing similar quotations having the same meaning under the same thematic areas. Validation of the study was achieved through a triangulation of data (i.e. the data was collected through multiple sources: interview and FGD), member checking (the informant served as a check throughout the analysis process) and peer examination (several colleagues were consulted at different phases to comment on the whole research process and to gain outsider perspective).

\section{Results and Discussion}

In the recent years, a number of new approaches have been developed to assess the achievement levels. In India, some of these methods have yet to be tried to establish their applicability. In the simplest of the terms, it may be mentioned that assessment should be viewed as a tool for improving educational standards, provide information to educators to determine which practice has resulted in desired outcomes and to what extent. The study has raised many issues that have serious implication for quality improvement in primary education. Some of these issues are discussed below.

To identify the main problems threatening the quality of primary education, discussions (FGD) and indepth interviews were conducted with the Head Teacher and Teacher-in Charge attending in-service training at Jhargram sub-division. The analysis in this section attempts to describe their perceptions of barriers to the delivery of quality education. To this end, the issue can be categorized into different themes and examined in detail.

\section{School Leadership}

Although school leadership play a paramount role in enabling students to learn, achieve and develop (Susi; Domenici \& Moretti, 2011), all the participants remarked that it was beset by many problems. They further stated that it was one of the causes of the decline in quality education.

Everybody agreed that school leadership made a different on students' learning by coordinating the efforts of teachers, motivating staff and creating a conductive environment for learning. However, the current nature of leadership in school was not playing its role as it should, and was surrounded by many problems. From the very beginning, the assignment of a principal was not based on merit, but on the political view of that person (i.e. a matter of political affiliation). This in turn led to the perception of school as a servant of a political on the part of students, teachers and the community, and resulted in a lack of trust among teachers, students and school administrators. Moreover, unnecessary interference from local administrators on school matters was significantly harming the discretion of school administrators.

The attention given to academic issues by school administrators was very limited because much of their time was taken up in dealing with non-school issues. They were given much work to do by the Election Commission of India and Block Development Office. Since they were assigned by those Election Commission of India and Block Development Office, they respect and follow their (office's) order irrespective of its benefits to school to secure the position of teachership.

The above quotes indicate that all the respondents were dissatisfied with the current state of school leadership. It was clear from the descriptions given that the leadership failed to ensure that schools provided high quality teaching and learning. Moreover, it is evident that more time was devoted to non- instructional activities.

\section{Quantity versus Quality Quandary}

The effort to achieve Universal Primary Education-one of the Millennium Development Goals-places heavy pressure on the Indian government, which is doing what it can to reach this objective. However, the respondents with whom we spoke during the data collection phase of this study strongly remarked that the focus on quantity (having as many children as possible) to meet the UPE goal overshadows the emphasis on quality of education. Here is an excerpt from one of the interviews: 
Currently, more than ever before, the issue of universal primary education is on the lips of everybody. This is mainly because the time limit for the realization of UPE is approaching i.e. 2015. So, much of the effort was given to expansion and to having many children in schools, and nobody cares about the quality of education. The implementation of a general education quality improvement programme did not bring the expected improvement and the priority was on quality. For example, students were promoted to the next grade regardless of their performance because it was believed that if students fail to pass to the next grade, they may drop out of education; and this in turn resulted in an increment of the number of students out of school and went to influence the UPE goal.

Correspondingly, another FGD group offered the following account

When someone builds a house, he first lays down a very strong and firm foundation which can support the whole building. If the foundation is not strong enough to support the building, it will fall down within a few years. The same is true for primary education. If we have good primary education, we have good secondary and tertiary education. It is a foundation for other successive levels. However, primary education has not received the attention it deserves, especially with regard to quality. Rather, the focus is on massification- having many children in schools and this will dysfunction the whole system of education.

The participants were clear that not having good primary education would make the students lose the desire to learn; as the content becomes more difficult, the increase in schooling level will result in dropout and loss of human capital. There is credible evidence that educational quality is of paramount importance in equipping learners with the required tools to face present and future challenges. However, the findings of the study revealed that the standard of education was poor and not given attention. Simply put, expanding enrollment has compromised the quality of education. This confirms the finding of the World Bank (2007) that the educational quality in developing countries in much worse than educational quantity (school enrollment and attainment). Likewise, Kedir (2006) argues that although politicians have been pushing for numerical growth, its consequence, as regards quality and relevance, is extremely devastating.

\section{Financial Milieu}

The importance of the economic environment for the delivery of quality education is unquestionable as the economy and its level of development impact organizational effectiveness. The respondents stated that the weak economic environment significantly influenced the education system in general and its quality in particular. The following quote was taken as illustrative of this opinion:

The community was expected to provide resources (financial and material) for the schools in their vicinity. However, because of the current inflation and growth of life expenses, the communities were unable to provide resources expected of them to support the school. So, the school system was running a critical shortage of resources to effectively run its various programs. Owing to this, equipping schools with different reading materials, computers and ICT, preparation of instructional aides, construction of new buildings and maintenance of the old ones was impossible for the school. Those problems impede the delivery of quality education and the weak economic environment diverts the attention of students toward searching for jobs to address their immediate needs such as food and water rather than concentrating on their education.

The following excerpt from the FGD participants affirms this view:

The socio-economic status of the student population was varied. Some parents were able to support their children while some were not. Students failing to gain support from parents do not attend their lesson properly because they have to engage in some work to generate income to their physiological needs and to support their education. So, they attend the class on days, i.e. if they attend class on one day, they then participate in some kind of income generation labor the next day. This takes up much of the students' time and prevents them from focusing on their education and on the other hand, as capital per income of each household is low, it is difficult for a school to obtain funds from the community to run its program smoothly. The community has failed to support children's education and the school due to economic problems.

The expansion and delivery of quality education requires a sufficient amount of money to build schools. However, the participants remarked that the weak economic environment harms the quality of education delivered to citizens. Although it was believed that communities can play a variety of roles in the provision and management of learning, the current state of the economy hinders this. Since the majority of the Jhargram population is on a low income, the struggle was to meet the basic needs (i.e. food, shelter) of survival.

\section{Teacher-Related Issues}

The important of teachers in educational change and school improvement was by many scholars (Muhammad, 2006; Goldhaber \& Anthony, 2004; UNESCO-IBE, 2003; Darling-Hammond \& Berry, 1998; Louden, 1991). It is what teachers think, believe and do in classroom that eventually shapes the learning of young people (Louden,1991). The insightful responses of the participants about the major barriers of quality education revealed that the way teachers trained, the salary they were paid and their professional development 
were major problems that threatened the delivery of quality education. The excerpt of an FGD participant clearly shows this:

The knowledge and skills teachers received during training were insufficient and failed to prepare teachers for the world of work. This was clearly shown by the teachers' inability to perform their roles and exercise their responsibilities effectively when they graduated and were assigned to schools. The complaints from the students where they taught also revealed this truth. Although they were trained and certified to teach at any grade level in primary schools, they failed to do so. Another informant offered this comment:

Educational institutes are producing dozens of ill-equipped, inefficient, incompetent and poor quality teachers not having the required knowledge, attitudes and skills to meet the demands of today's work place, i.e. graduates who are not able to teach in today's schools.

It is generally acknowledged that promoting teacher is the key to improving primary and secondary education. According to the European Trade Union Committee for Education-Etuce (2008), a high quality teacher education is essential at all levels, as well as the high status of the profession itself. This description strengthens the argument that there is no educational system that can rise above the quality of its teachers. Given this truth, the participants all agreed that the training teachers acquired failed to prepare them for the realities and demands of the workplace. So it can be inferred that the inability to produce qualified teachers (who will effectively discharge their roles and responsibilities) was jeopardizing education, which relies heavily on the preparedness of its teachers (Adeosun et al., 2009). These findings accorded with Jerome's (1997) contention that, in today's education system, students are graduating from college unprepared to meet the demands of society. The teacher is the most important factor influencing the quality of education (Hattie, 2003; Barber \& Mourshed, 2007). Emphasizing the importance of teachers, Darling- Hammond (2006) argues that, among all educational resources, teachers' abilities are especially crucial contributors to students' learning. Conscious of this, the government of India established a reform agenda for the teacher education program-making lesson student-centered and providing adequate school based on real life experience. The intention is to address the deep-rooted problem of quality in primary schools by providing teachers with a range of knowledge, skills, attitudes and relevant educational experience. Indeed, improving teacher quality usually does improve student achievement and this can occur when teachers are appropriately trained. What and how teachers teach directly impact what and how students learn. And what and how teachers teach depends on the knowledge, skills and attitude they bring to classroom. Hence, if there is a need to improve the quality of education, teachers must be provided with powerful learning opportunities that meet the demands and realities of $21^{\text {st }}$ century schools. Sharma (1993) argues that the quality of teachers depends on the teachers' educational qualifications and quality of pre-service and in-service teacher training. Teacher training thus takes great importance in building and achieving quality education. So, it is imperative for the government of India to reconsider and take the necessary steps to assure that teacher trainees receive adequate training and experience. In discussing teacher related issues, all the informants from the FGD and the interviewees strongly agreed that the teachers' salary is a key issue of education. The interviewed Head Teacher and Teacher-in-Charge revealed that a "low salary" influences the quality of education because it affects the motivation of school staff. This was substantiated by a discussant of the FGD:

In comparison with other government workers, teachers have a low salary. The other benefits and incentives teachers receive are also either very poor or non-existent. This leads teachers to hate the teaching profession and regard it as a bridge occupation i.e. they want to stay in teaching only until they find another job. Teachers are leading a very low standard of living. They fail to cope with the current cost of living. So, teachers are not on what the students learn and how they learn, but rather they are worrying about their life and with this problem, how can teachers be interested and initiated to maintain the quality of education? To this may be added a comment from another FGD informant:

When we compare the salary of teachers with other workers working in different sectors, teacher are not well paid. We are living and working in the same environment; we consume raw materials from the same market, the same shop with other workers. By observing the salary structure of workers, someone can easily understand that teachers are less paid. In particular, one of the informants felt strongly about the issue of low pay:

Paying a low salary for teachers is unrecognizing their effort of helping and preparing the generation. Paying less in another language is that he is not doing a productive job. This is very disgusting. So, it is very difficult to find someone who is interested is being a teacher, as teaching is suffering.

The participants' explanations generally suggested that the vast majority of teachers used up their monthly salary before the month ended. They indicated that their salary disappeared from their pockets without covering the expense of basic costs (food, house rent, etc). Owing to this fact, teachers do not worry about what and how the students learn; instead they have their own concerns. Continuing their discussion, the participants remarked that people develop negative attitudes towards the profession and choose to leave if they have other options. They believed that they did not receive the benefit they deserved from the profession, which left them 
dissatisfied. They further explained that the issue of salary also dissuaded young people from becoming teachers; it is a challenge for the teaching profession to attract academically capable students. The response indicated that most teachers were looking for other options (to be employed in other sectors). It seems logical, therefore, to improve the standing of all teachers by ensuring that they are paid a salary comparable with other professions requiring the same level of qualifications and responsibilities, and that it is possible for them to live with dignity and not be forced to look for other jobs. As regards teaching barriers, according to the participants, the present continuous professional development opportunities were very limited and problematic. Maintaining this view, one FGD participants explained that:

From the very beginning, we (Head Teachers and Teacher-in-Charge) don't have the required information about the continuous professional development currently under implementation. Owing to this, we were confused about what it is and how it is implemented. Because it was designed at the top (i.e. by the Ministry of Education) and prescribed to us (the schools) for implementation. We don't have sufficient awareness about it, so what we (Head Teacher and Teacher-in-Charge) did is to tell teachers to participate in it. When asked to explain the issue by teachers, we told them it was the Ministry of Education's plan, so do it and we were confused and confusing our teachers and teachers did not accept it positively. Another informant similarly explained:

Professional development is something imposed on us from the outside. Therefore, we do not have other options rather than participating. We participate to comply with the rule and not to be punished. No one is there to support teachers and to explain the activities to them. So, it is something done to us, not for us.

For Komba and Nkumbi (2008), teacher professional development provides opportunities for teachers to explore new roles, develop new instructional techniques, refine their practice and enhance themselves both as educators and as individuals. Correspondingly, Guskey (2002) argues that high quality professional development is a central component in nearly every modern proposal for improving education. Adding to this argument, Fredriksson (2004) states that the professional development of teachers is a key guarantee of quality education and must be linked to all phases of teacher training and educational research. However, information obtained from the respondents indicated that the current professional development of teachers had many defects and was not positively perceived. According to American Federation of Teachers (2002), without professional development, school reform and greater achievement among all students will not happen. It is, therefore, imperative to give due attention and to provide support for the professional development of teachers if the quality of education is to be improved.

\section{Parents' Partaking}

The role of parent in managing children's educational experiences at home and at school has been considered critical for success. Indeed, Desforges and Abouchaar (2003) assert that if pupils are to maximize their potential from schooling, they will need the full support of their parents. However, the participants with whom we spoke during the data collection believed that the current state of parents' participation is low and not as expected. The following excerpt was taken as an illustration of this:

Parents didn't follow the progress of their children. They didn't support them. When students commit disciplinary violations, we inform the parents about the misbehavior of their children, but they deny and reply "my child didn't misbehave" instead of correcting and advising them....there is almost no communication between the school and the parents. They contact the school infrequently, when obliged to, or when their children commit a disciplinary violation...we can boldly say that parents were isolated from the school and did not help the school effort to improve school performance.

A number of research studies show that parental involvement in children's learning activities positively influences their levels of achievement and their motivation to teach (Epstein, 1992). However, the findings of this study indicated that parental involvement is low; they did not support the school system improve students' learning. During the discussion, the participants claimed that the parents' educational level and socioeconomic background were the main reasons for this low involvement. In the course of data collection, the discussants argued that "because illiteracy parents don't follow the progress of their children's learning: what do they learn? How do they learn? Why do they learn?". This response corresponded to UNESCO's (2000) finding that parents' level of education has a multifaceted impact on children's ability to learn in school.

\section{Commercialization of the Teacher-Training Programme}

Although the expansion of teacher-training institute is considered an opportunity for the government to address the shortage of qualified teachers, all the participants agreed that it significantly harmed the quality of education. The following quote is reflective of this view:

Using the critical shortage of teachers as an opportunity, private institutions were opened in every corner of the country with poor resources, ill equipped library, no ICT center, no sports facilities, unqualified teaching staff and improper classroom mainly constructed for other purposes ( not as classrooms). Their major 
concern was the profit they make out of this. The fact that the candidates joining the private institutions were those who cannot join government higher education because of low Grade Point Average was also a critical issue that worsens the problem. The screening power of their evaluation mechanism was also weak with the intention to promote all students with the next year level so that they can have more students to have more profit. The highly corrupted individuals within the system of the government structure at different levels, such as zone and region, who were in charge of monitoring and controlling the quality of education they delivered were creating a supportive environment for them and were worsening the situation.

Another informant reported that the way teachers trained was a cause for declining quality, as it was considered a profitable area, like any other commodity.

If you look at the Cumulative Grade Point Average (CGPA) of new graduates from private institutions, it is really amazing. You don't believe it. You can't see any one above 3.5. However, when you evaluated them in practice, they are very poor in many aspects like content knowledge, teaching methodology, classroom management etc. This is because the concerns of training institutes were not of equipping them with the required knowledge, but the profit they make.

Research on teaching has demonstrated that qualified teachers can improve student performance (Darling-Hammond, 2000), and achieving this for all requires educators to pay closer attention to what teachers do in the classroom (GORE et al., 2001). Such a move seems logical in order to have well qualified teachers in the system. The data obtained from the participants clearly revealed that teacher-training institutes were treated as commodities; the rise in the number of private teacher-training institutes was viewed as a massive profitmaking opportunity. As a result, the focus on profit overshadowed the focus on quality. The participants further indicated that corrupt individuals within the government created an environment within which private colleges could operate in very poor conditions that significantly affected the quality of education. This finding supported Girma's (2010) observation that the massification of private higher education institutes leads to lower standards. Undoubtedly, private higher education institutes play a significant role in the nation's human resource development. However, the problem is the ideology behind theses corporate organizations. Driven by profitmaking desires, they consider students for profit, recruit under-qualified staff, operate in poor conditions and make quick programs to maximize their benefits or economic rewards.

\section{Conclusion and Practices for Implication}

The results of this study are supposed to have some realistic allusion, which might highlight areas of intrusion to improve the quality of primary education. To this end, below are some of the major implications to be addressed.

a) The first implication of this research study is the need to improve school leadership, which is the greatest determinant of an organization's success. Similarly, it plays a pivotal role in improving the quality of education that promotes effective teaching and learning for all students. It is, therefore, imperative for government to develop school leadership by making the assignments of Head Teachers based on merit rather than political affiliation. In this way, they can help their schools meet ever-evolving and increasingly complex expectations.

b) The second implication of the results was the need to balance the quantitative and qualitative development of education. Education of the highest quality is essential and enables people to face social, cultural, economic and technological challenges. In order to meet this objective, an education system must maintain its quality along with its expansion.

c) The third implication of the results was the need to provide adequate funds for schools. As the findings of the study revealed, schools were suffering from a lack of resources. Relying on the surrounding community was not promising as its income was not enough to sustain its members, let alone fund schools. For this reason, intervention was needed by the government to provide adequate funds so that schools are equipped with the necessary teaching-learning materials and have additional classrooms and chairs.

d) The fourth implication of the results of this study was resolving teachers' problems. Teachers constitute a very prominent component of the educational system. What they do matters more for student learning than any other single factor. Hence, the following points should be considered by prospective stakeholders in order to make more effective use of school teachers.

e) Ensure that teachers receive proper, adequate and relevant initial and in-service training/education at university level to prepare them for work as teachers. Provide a salary comparable with that of other professions requiring the same level of qualifications and responsibility. Ensure that teachers receive the recognition appropriate to their level of qualifications and responsibilities. 
f) The fifth implication of the findings of the study was the need to design effective professional development opportunities. We are living in a very dynamic, complex and interconnected world. This is turn requires schooling to change continuously in order to meet the needs of a changing society and to address the existing problems of education. to this end, designing effective, school-based and collaborative professional development opportunities is vital as it improves the processes of teaching and learning. The system also needs to provide all the resources and information required by teachers so that they can approach their work with an orientation to change. Moreover, the Head teachers and Teacher-in -Charges need to empower staff members to be responsible for their own professional development.

g) The final implication of the findings of the study was that of strengthening the relationship between parents and schools. Parent/family involvement significantly contributes to improving student performance in a variety of ways. However, parental involvement in education is insufficient and, therefore, it is very important to increase their role in promoting the social, emotional and academic growth of their children. It is also fundamental for schools to recognize the interdependent nature of their relationship with parents, who should be valued as essential partners in their education process.

\section{References}

[1]. Adeosun, O. et al. (2009). Teacher training quality and effectiveness in the context of basic education: An examination of Primary Education Studies (PES) programme in two Colleges of Education in Nigeria. Journal of International Cooperation in Education, 12 (1), 107-125.

[2]. American Federation of Teachers (2002). Principles for professional development. Washington, DC: Author.

[3]. Auger, G. A (1977). Evolution of the concept of basic education in Eastern Africa. Nairobi: Kenyata University.

[4]. Barber, M., \& Mourshed, M. (2007). How the world's best- performing schools come clientservice/socialsector/resources/pdf/ World_School_systems_final.pdf.

[5]. Barth, R. (1991). Improving schools from within. San Francisco: Jossey-Bass.

[6]. Bogdn, R. C.,\& Biklen, S. K (1992). Qualitative research for education: An introduction to theory and methods. Boston, MA: Allyn $\&$ Bacon.

[7]. Chimombo, P. G. (2005). Issues in basic education in developing countries: An exploration of policy options for improved delivery. Journal of International Cooperation in Education, 8(1), 129-152.

[8]. Csizmadia, T.G. (2006). Quality management in Hungarian higher education. Organizational responses to governmental policy. The Netherlands: CHEPS/UT.

[9]. Darling-Hammond, L. (2000). Teacher quality and student achievement: A review of state policy evidence. Education Policy Analysis Archives, 8(1), retrived from http:// www.epaa.edu.

[10]. Darling-Hammond, L. (2006). Constructing $21^{\text {st }}$ century teacher education. Journal of Teacher Education, 57(3), 300-314.

[11]. Darling-Hammond, L., \& Berry, B. (1998). Investing in teaching: The dividend in student achievement. Education Week, 27,48, retrieved from http://www.teachingquality.org/pdfs/bb_cv.pdf.

[12]. Dawson, C. (2002). Practical research methods. A user-friendly guide to mastering research techniques and projects. United Kingdom: Cromwell Press.

[13]. Desforges, C., \& Abouchaar, A. (2003). The impact of parental involvement, parental support and family education on Pupil achievement and adjustment: A literature review. Research Report RR433. UK: Department for Education and Skills.

[14]. Domenici, G., \& Moretti, G. (a cura di). (2011). Leadership educative e autonomia scolastica. Il governo dei processi formative e gestionali nella scuola di oggi. Roma: Armando.

[15]. Epstein, J. L. (1992). School and family partnerships. In M. Alkin (Ed.), Encyclopedia of educational research (6 ${ }^{\text {th }}$ ed.). New York: MacMillan

[16]. ETUCE-European Trade Union Committee for Education (2008). Teacher education in Europe. An ETUCE policy paper.

[17]. Fredriksson, U. (2004). Quality education: The key role of teachers. Education International working papers, 14

[18]. Fullan, M. (2005). Leadership and sustainability: System thinkers in action. Thousand Oaks, CA: Crown Press.

[19]. GCE-The Global Campaign for Education (2002). A quality education for all: Priority actions for governments, donors and civil society. GCE Briefing Paper, retrieved from http://www.campaignforeducation.org .

[20]. Girma, M. (2010). An assessment of the current status of quality of education in private higher education institutions: The case of Mekelle. Unpublished MA Thesis, Addis Ababa University, School of Graduate Study.

[21]. Glesne,C. (1999). Becoming qualitative researchers: An introduction ( $2^{\text {nd }}$ ed.). New York: Longman.

[22]. Goldhaber, D.,\& Anthony, E. (2004). Can teacher quality be effectively assessed? Seattle: University of Washington.

[23]. Guskey, T.R. (2002). Professional development and teacher change. Teachers and Teaching: Theory and Practice, 8(3/4), 381-391, retrieved from http://dx.doi.org/10.1080/135406002100000512.

[24]. Haddad,W. (1990). Education and development: Evidence for new priorities. World Bank Discussion Papers.

[25]. Harvey, L., \& Green, D (1993). Defining quality. Assessment and Evaluation in Higher Education. 18(1), 9-34.

[26]. Hattie, J.(2003). Teachers make a difference. What is the research evidence? Australian Council for Educational Research, retrieved from http://www.det.nsw.edu.au/proflearn/docs/pdf/qt_hattie.pdf.

[27]. Komba, W.L.,\& Nkumbi, E.(2008). Teacher professional development in Tanzania: Perceptions and practices. Journal of International Cooperation in Education, 11(3), 67-83.

[28]. Lloyd-Jones, G. (2003). Design and control issues in qualitative case study research. Journal of Qualitative Methods, 2(2), retrieved from http://www.ualberta.ca/_iiqm/backissues/2_2/pdf/lloydjones.pdf.

[29]. Lockheed, E.M., \&Verspoor , A.M. (1991). Improving primary education in developing countries. Washington, DC: World Bank.

[30]. Louden, W. (1991). Understanding teaching. Continuity and change in teachers' knowledge. London: Cassell.

[31]. Merriam, S. (1988). Case study research in education: A qualitative approach. San Francisco: Jossey-Bass.

[32]. Mirza, S. M. (2003). Quality of primary education in Pakistan . Preparatory Document for the Ministerial Meeting of South Asia EFA Forum, 21-23 May. 
[33]. Muhammad, N.H. (2006). Quality education needs quality teacher: Our education our thoughts. Campaign for Popular Education, Bangladesh.

[34]. Psacharopoulos,G. (1985). Returns to education. A further international update and implications. Journal of Human resources, 20(4), 583-604, retrieved from http://www.jstor.org/about/terms.html.

[35]. Reddy,S. (2007). School quality: Perspectives from the developed and developing countries. AzimiPremiji Foundation.

[36]. Sergiovanni, T.J. (2001). The principal ship: A reflective practice perspective. Boston, MA: Allyn \&Bacon.

[37]. Sharma, M (1993). Teacher education: The quest for quality. In E. Thomas et al., Professional development of teachers: Policy and Practice in initial teacher training. London: Commonwealth Secretariat.

[38]. UNESCO (2005). EFA Global monitoring report. The quality imperative.

[39]. UNESCO(1997). Educating for sustainable future: A transdisciplinary vision for concerted action. EPD-97/CONF.401/.

[40]. UNESCO-IBE (2004). Quality education for all young people. Reflections and contributions emerging from the 47th International Conference on Education of UNESCO, Geneva.

[41]. UNICEF (2000). Defining quality. Working paper serious, education section, program division. A Paper presented at the International Working Group on Education Meeting, Italy.

[42]. World Bank (2007). Education quality and economic growth. Washington, DC: World Bank.

[43]. World Bank (1988). Education for Sub-Saharan Africa. Policy for adjustment, revitalization and expansion. Washington, DC: World Bank. 